\title{
Ingestion of gametes by protists: fate of surplus reproductive energy in the sea
}

\author{
Helena M. Galvão ${ }^{1 *}$, Alyce T. Fritz ${ }^{1}$, Rolf Schmaljohann ${ }^{2}$ \\ ${ }^{1}$ Virginia Institute of Marine Science, Gloucester Point, Virginia 23062, USA \\ ${ }^{2}$ Abt. Marine Mikrobiologie, Institut für Meereskunde, Düsternbrooker Weg 20, D-2300 Kiel 1, Federal Republic of Germany
}

\begin{abstract}
Considerable amounts of biomass are expended by both multicellular and unicellular organisms for reproductive processes and for free release of gametes into the sea. Despite considerable attention to egg mortality in the literature, the fate of the large excess of male gametes still remains to be elucidated. Intensive ingestion and digestion of bivalve spermatozoa by microprotozoans was observed in a temperate salt-marsh (Chesapeake Bay, USA) and laboratory experiments confirmed this phenomenon. Thus, it is proposed that the microbial food web serves as an important recycling pathway for the rapid and efficient utilization of a substantial fraction of this reproductive energy. Furthermore, in the laboratory, microprotozoan growth was stimulated through grazing of gametes, which constitute a particularly rich food source with low $\mathrm{C}: \mathrm{N}$ atomic ratio and high $\mathrm{C}, \mathrm{N}$ and P cellular contents. The extent to which this 'reversed food chain' affects current estimates of the energy/food budget in the sea is still unknown, but deserves further investigation.
\end{abstract}

\section{INTRODUCTION}

The complexity of trophic interactions within the microbial food web (Pomeroy 1974, Azam et al. 1983) has been the subject of intensive investigation. Protists have been shown to possess a variety of trophic behaviours and are capable of utilizing diverse food sources (e.g. Campbell \& Carpenter 1986, Estep et al. 1986, Suttle et al. 1986). To further document this complexity, the present study presents evidence of an alternative microbial food web pathway, whereby metazoans in their reproductive stages constitute a prey reservoir for microprotozoans, thus reversing the food chain. Moreover, although egg mortality has been discussed to some extent in the literature, the fate of excess sperm released during spawning has yet to be documented or thoroughly discussed by marine ecologists. Since male gametes constitute a significant contribution to the energy budget in certain areas of the sea (Dundas 1985), ingestion of male gametes by protists represents the elucidation of a potentially important 'missing' link.

In the course of intensive field-sampling in a temper-

\footnotetext{
- Present address: Abt. Marine Mikrobiologie, Institut für Meereskunde, Düsternbrooker Weg 20, D-2300 Kiel 1, Federal Republic of Germany
}

ate salt-marsh system in the vicinity of the Chesapeake Bay, USA, epifluorescence microscopy revealed considerable grazing of bivalve flagellated gametes by protists. In some water samples, unpigmented cryptophytes showed ingestion of 5 gametes cell-1, and aloricate ciliates and heterotrophic dinoflagellates as many as 20 to 30 gametes cell $^{-1}$. Bivalve spermatozoa were easily identified by brightly fluorescent enlarged nuclei with species-specific shapes and single long flagella. Shapes varied from spherical to conical, crescent or 'corkscrew', and sizes ranged from 1 to $2 \mu \mathrm{m}$ diameter and from 2 to 5 um length. Spawning events occurred throughout the sampling period (July to December 1982) and pulses reached $10^{4}$ to $10^{5}$ flagellated gametes $\mathrm{ml}^{-1}$. The predominant bivalve 'donor' species were identified as Geukensia demissa (ribbed mussel), Crassostrea virginica (American oyster) and Mya arenaria (soft clam). Protists showed ingestion capacities ranging from 30 to $100 \%$ (\% cells showing ingested gametes) during major spawning events.

\section{MATERIALS AND METHODS}

Water was taken from a salt marsh in the lower York River, Virginia, USA, on 3 June 1984. In the laboratory, it was pre-filtered through $15 \mu \mathrm{m}$ Nitex screen, or 
through $3 \mu \mathrm{m}$ and $8 \mu \mathrm{m}$ Nuclepore membrane, resulting in 3 water fractions with different mean-sized nanoplankton ( 2 to $20 \mu \mathrm{m}$ size protists) populations, which are referred to as $<15 \mu \mathrm{m},<3 \mu \mathrm{m}$ and $<8 \mu \mathrm{m}$ treatment/cultures. In $<15 \mu \mathrm{m}$ cultures, grazer populations included, besides nanoflagellates, small ciliates and non-pigmented dinoflagellates. Water fractions were incubated in polycarbonate diffusion chambers equipped with $0.2 \mu \mathrm{m}$ Nuclepore membrane, which permitted rapid diffusion of solutes to approximate in situ conditions (Rhodes et al. 1983). Chambers were placed in a flow-through tank supplied with estuarine water. After $24 \mathrm{~h}$ and development of healthy nanoplankton populations, chambers were inoculated with freshly released gametes of a male specimen of Crassostrea virginica. Epifluorescence microscopy counts using proflavin as a fluorochrome (Haas 1982) were performed at different time intervals to estimate growth and grazing rates of heterotrophic nanoflagellates. $C$. virginica spermatozoa were also inoculated into $1.2 \mu \mathrm{m}$ filtered (Whatman GF/C glass fiber filters) marsh water to control for autolysis and bacterial degradation.

For particulate carbon and nitrogen analyses, various aliquots of Crassostrea virginica spermatozoa in $0.2 \mu \mathrm{m}$ sterile filtered marsh water were filtered onto $450^{\circ} \mathrm{C}$ $(6$ h) precombusted Whatman GF/F filters. Filters were dried overnight at $60^{\circ} \mathrm{C}$ and processed through a Perkin Elmer model $240 \mathrm{~b}$ Elemental Analyzer. At the end of the $20 \mathrm{~h}$ incubation period, chamber cultures were sacrificed for transmission electron microscopy (TEM). Water samples were pre-fixed with $3 \%$ glutaraldehyde in $0.1 \mathrm{M}$ sodium cacodylate buffer for $2 \mathrm{~h}$ at $4^{\circ} \mathrm{C}$. After repeated buffer washes and centrifugation procedures (690 $\times g$ for $5 \mathrm{~min}$ ), pellets were postfixed in $1 \%$ osmium tetroxide in $0.19 \mathrm{M} \mathrm{NaCl}$ for $2 \mathrm{~h}$ at $4^{\circ} \mathrm{C}$. Pelleted cells were then enrobed in agar and, after dehydration through a graded acetone series, embedded in EPON 812. Uranyl acetate/lead citrate stained ultrathin sections were examined with a Zeiss EM9 electron microscope.

\section{RESULTS}

Larger mean-sized heterotrophic nanoflagellates in $<15 \mu \mathrm{m}$ treatments showed maximum ingestion capacities of 70 to $80 \% \quad \%$ cells with ingested gametes), whereas smaller mean-sized populations in $<3$ and $<8 \mu \mathrm{m}$ treatments only 30 to $40 \%$ (Fig. 1). These maxima were reached within 2 to $4 \mathrm{~h}$, after which flagellate ingestion capacity declined and then stabilized. It is to be noted that in one of the $<15 \mu \mathrm{m}$ cultures, the first sampling ( $\mathrm{T}=\mathrm{O}$ ), showed $20 \%$ of heterotrophic nanoflagellates already with ingested gametes (Fig. 1). This could be explained by rapid prey recognition and ingestion processes, in the order of seconds, between gamete inoculation and first sampling $(<1 \mathrm{~min})$, since prior to inoculation, no gametes were observed in the water.

Higher growth rates of heterotrophic nanoflagellates (Table 1) were found in the presence of gametes (overall mean 2.7 divisions $\mathrm{d}^{-1}$ ) than in control chambers without gametes (mean $1.4 \mathrm{div}, \mathrm{d}^{-1}$ ). Maximum growth rates of 5.9 div. $\mathrm{d}^{-1}$ and 8.3 div. $\mathrm{d}^{-1}$ in the $<3 \mu \mathrm{m}$ and $<15 \mu \mathrm{m}$ cultures, respectively, were observed in the second half of the incubation period.

Particulate carbon and nitrogen analyses performed on Crassostrea virginica male gametes revealed C:N atomic ratios of $3.2 \pm 0.2$. Each spermatozoan contained $6.11 \mathrm{pg} \mathrm{C}$ and $2.24 \mathrm{pg} \mathrm{N}$. With a total biovolume (flagellum, mitochondria and acrosome included) of $5.0 \mathrm{\mu m}^{3}$, calculated from TEM and epifluorescence microscopy measurements, carbon and nitrogen cellular contents per $\mu \mathrm{m}^{3}$ were $1.22 \mathrm{pg}$ and $0.45 \mathrm{pg}$, respectively. This corresponded to a chemical composition of $44 \%$ carbon and $16 \%$ nitrogen on a dry weight basis assuming ca $60 \% \mathrm{C}+\mathrm{N}$ (Dundas 1985).

Ultrathin sections under electron microscopy (Fig. 2) revealed intensive ingestion and digestion of oyster spermatozoa by heterotrophic nanoflagellates (Fig. 2b to e). Sperm flagella were not observed to be ingested. In Fig. 2a, a longitudinal section shows a cellular struc-

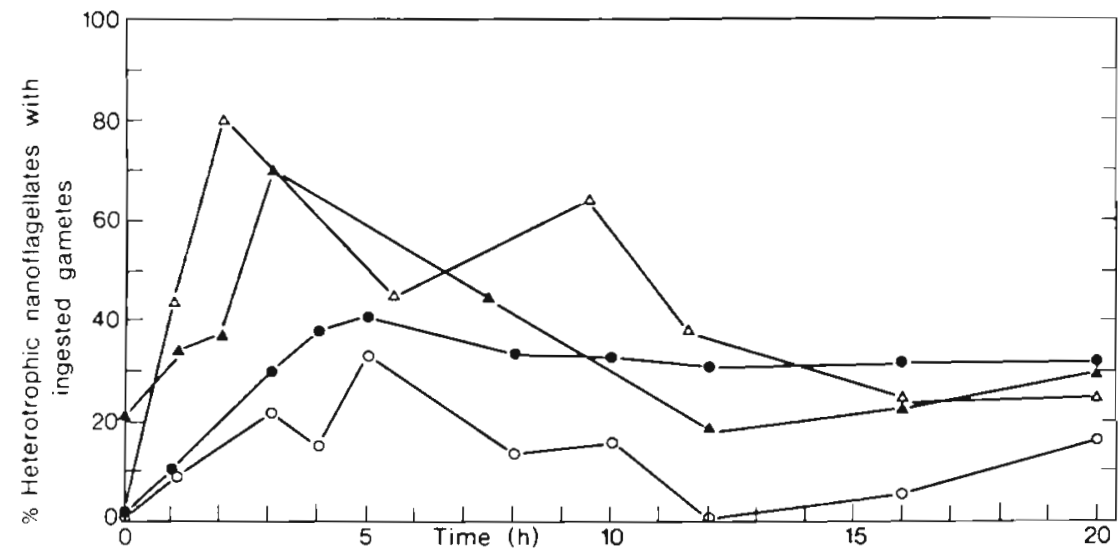

Fig. 1. Ingestion capacity of heterotrophic nanoflagellates during a $20 \mathrm{~h}$ incubation with oyster gametes (Crassostrea virginica). (A, $\Delta)$ Duplicate $<15 \mu m$ treatments; (0) single $<3 \mu \mathrm{m}$, and $(\bullet)<8 \mu \mathrm{m}$ treatments 
Table 1 Growth and grazing rates of nanoflagellates with and without gametes in differentially filtered marsh water

\begin{tabular}{|c|c|c|c|c|}
\hline Culture & $\begin{array}{l}\text { Nanoflagellate growth } \\
\text { (div } \mathrm{d}^{-1} \text { ) }\end{array}$ & $\begin{array}{l}\text { Nanoflagellate final } \\
\text { conc. }\left(\times 10^{3} \text { cells } \mathrm{ml}^{-1}\right)\end{array}$ & $\begin{array}{l}\text { Mean prey conc. } \\
\left(\times 10^{5} \mathrm{ml}^{-1}\right)\end{array}$ & $\begin{array}{c}\text { Prey grazed no. } / \text { blomass }^{b} \\
\left(\% / \mu \mathrm{g} \mathrm{C} \mathrm{ml} l^{-1}\right)\end{array}$ \\
\hline$C<15 \mu \mathrm{m}^{\mathrm{c}}$ & 1.4 & 17 & 91 & $100 / 0.21$ \\
\hline$<15 \mu \mathrm{m}^{\mathrm{d}}$ & 3.4 & 14 & 7.4 & $42 / 1.01$ \\
\hline$<8 \mu \mathrm{m}^{\mathrm{d}}$ & 1.6 & 7.8 & 3.3 & $28 / 0.31$ \\
\hline$<3 \mu \mathrm{m}^{\mathrm{d}}$ & 2.5 & 4.5 & 4.8 & $14 / 0.23$ \\
\hline \multicolumn{5}{|c|}{$\begin{array}{l}\text { a } \% \text { prey number grazed; for } \mathrm{C}<15 \mu \mathrm{m} \text { : \% bacteria production grazed on a cell number basis assuming } 24 \text { h generation time } \\
\text { b Total biomass grazed during } 20 \mathrm{~h} \text { incubation; for } \mathrm{C}<15 \mu \mathrm{m} \text { : bacterial biomass estimated assuming } 0.073 \mu \mathrm{m}^{3} \text { average } \\
\text { volume and } 380 \mathrm{fg} \mathrm{C} \mathrm{mm}^{-3} \text { carbon content (Lee \& Fuhrman 1987); for experimental cultures: } 3.3 \mathrm{pg} \mathrm{C} \text { per sperm head }(2.7 \\
\mu^{3} \text { ) } \\
\text { c Mean of } 2 \text { control (without gametes) }<15 \mu \mathrm{m} \text { cultures grazing on bacteria } \\
\text { d Mean of } 2 \text { experimental (with gametes) }<15 \mu \mathrm{m} \text { cultures; }<8 \text { and }<3 \mu \mathrm{m} \text { single experimental cultures }\end{array}$} \\
\hline
\end{tabular}
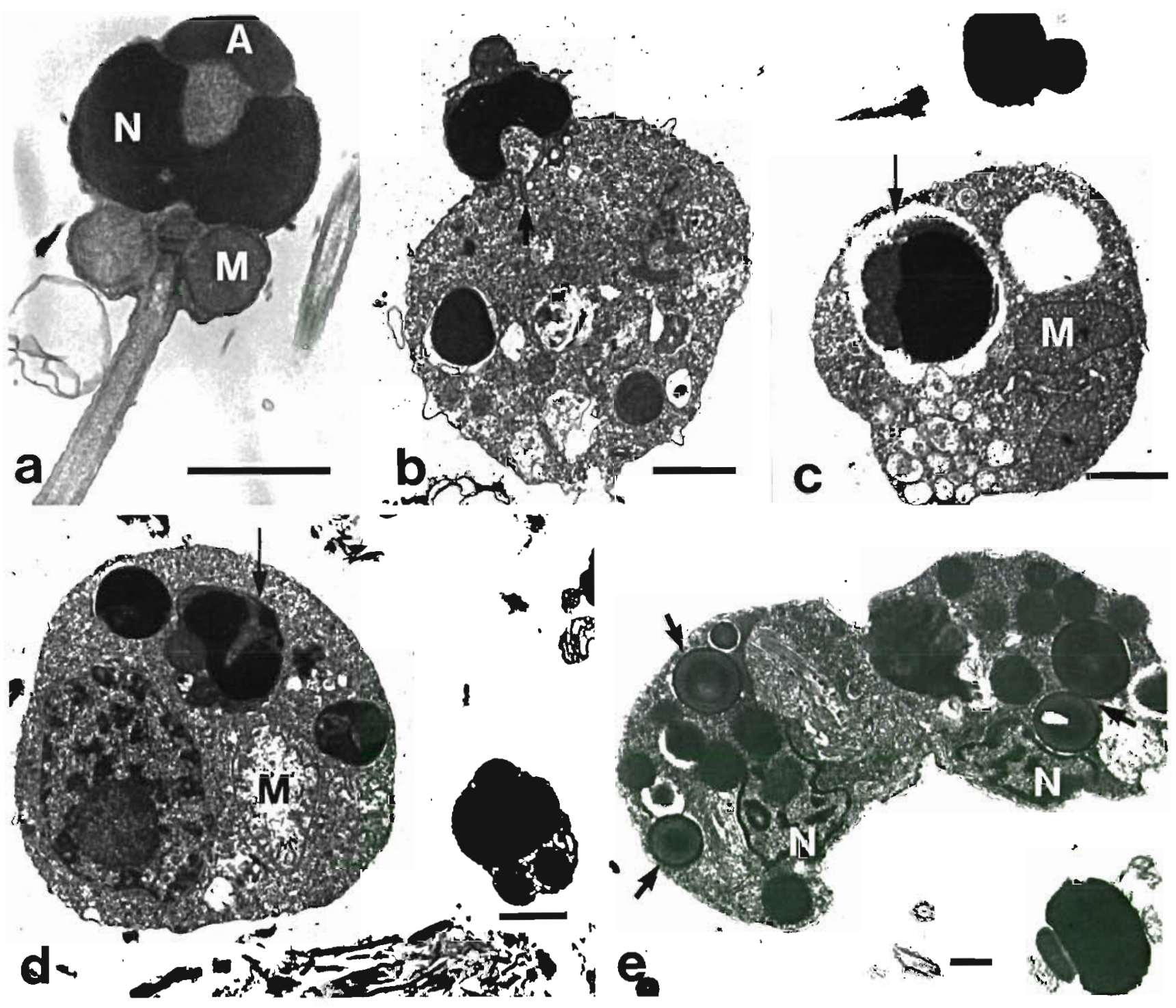

Fig. 2. Transmission electron micrographs of ultrathin sections of Crassostrea virginica spermatozoa (a to e) and heterotrophic nanoflagellates (bodonids, $b$ to e) showing different gamete ingestion/digestion stages. (a) Spermatozoan section with cup-shaped nucleus $(N)$, 4 spherical mitochondria $(M)$ around insertion point of single long flagellum, blunt-tipped acrosome (A). (b) Early ingestion stage with invagination of cytoplasmic membrane (arrow). In (c) and (d), arrows indicate food vacuoles containing a recently ingested spermatozoan. (e) Last stage of cell division shows electron-dense globules (arrows), indicating digestion endproducts of spermatozoan nucleic material. Scale bars $=1.0 \mu \mathrm{m}$ 
ture typical of relatively 'primitive' spermatozoa. This includes a well-developed short-tipped acrosome, a sub-spherical nucleus (1.7 um diam.) and a crown of 4 spherical mitochondria (only 2 visible in micrograph) surrounding a single long flagellum ( 40 to $42 \mu \mathrm{m}$ length measured with epifluorescence microscopy).

\section{DISCUSSION}

\section{Protozoan growth and grazing rates on gametes}

Growth stimulation of non-pigmented nanoflagellates in the experimental cultures was not surprising, since gametes provided ca 4 times more food (total biomass grazed) than bacteria (see $<15 \mu \mathrm{m}$ cultures, Table 1). It is interesting that the ingestion capacity of nanoflagellates reached a minimum during the maximum growth period (last $10 \mathrm{~h}$, Fig. 1). This was perhaps due to extremely rapid cell division hampering further ingestion processes. To illustrate this point, in Fig. 2e, a flagellate undergoing cell division reveals considerable amounts of digested spermatozoan material, but no evidence of recent ingestion.

Since $<15 \mu \mathrm{m}$ cultures grazed a mean of $42 \%$ of gametes total biomass grazed $1.01 \mu \mathrm{g} \mathrm{C} \mathrm{ml}^{-1}$ after $20 \mathrm{~h}$ (Table 1), it is reasonable to assume that the total microbial grazer population present in salt-marsh water could turn over $\geq 50 \%$ of gametes in $24 \mathrm{~h}$ during major spawning events with gamete concentrations exceeding $10^{5}$ cells $\mathrm{ml}^{-1}$. These concentrations were perhaps not unrealistically high, since 1 specimen of Crassostrea virginica was estimated to release 1 to $2 \times$ $10^{10}$ spermatozoa in 1 spawning event and all oysters in the same area will spawn simultaneously. Thus, the microbial community in the immediate vicinity of bivalve beds could encounter gamete concentrations in this order of magnitude, if not higher, particularly at low tide.

Crassostrea virginica spermatozoa controls in $\mathrm{GF} / \mathrm{C}$ filtered marsh water decreased by only $5 \%$ after $24 \mathrm{~h}$ at room temperature, mostly due to autolysis (observed after $20 \mathrm{~h}$ with electron microscopy) and subsequent bacterial breakdown. Therefore, the considerable biomass expended for reproductive processes (30 to $40 \%$ of bivalve biomass; Giese \& Pearse 1979) could be at least 10 times more rapidly recycled through grazing action than through other degradation processes.

\section{Cellular contents of male gametes}

Dundas (1985) likewise found a relatively high $\mathrm{N}$ :C ratio and low $\mathrm{N}: \mathrm{P}$ ratio in male fish gonad material, suggesting a potential rich source of nitrogen and phosphorus in the marine environment. It was further postulated in that study that fish sperm and sperm debris not only stimulate bacterial productivity, but also represent a nutritional input to microprotozoa, while partial degradation products of sperm DNA, such as guanine and hypoxanthine, could be utilized by primary producers before complete remineralization. Other salvage pathways are probably present in the nucleoprotein metabolism of protozoa. Remineralization of excess fish sperm in permanent water masses of oceanic gyres would increase the nutrient content (phosphate and nitrogen in particular) of these masses, thereby also enhancing prey densities available to fish larvae due to an overall stimulation of the microbial food web (Dundas 1985).

The nucleoplasm of fish sperm was reported to consist of 38 to $48 \%$ DNA and 33 to $49 \%$ protamine with the absolute a mount of DNA per spermatozoan varying considerably between different groups of fishes (Ginzburg 1972). The $C: N$ atomic ratio of 3.2 found in Crassostrea virginica sperm cells reflects their high DNA content (DNA $C: N<3$ and protein $C: N \approx 4$ to 5 ). Carbon and nitrogen cellular contents approached the high end of the range of nucleoplasm contents found in fish spermatozoa, which have a chemical composition similar to mollusc sperm, namely 0.6 to $1.4 \mathrm{pg} \mathrm{C} \mu \mathrm{m}^{3}$ and 0.2 to $0.5 \mathrm{pg} \mathrm{N} \mathrm{mm}^{3}$ (calculated from Salmo sp. in Ginzburg 1972). Although these values seem high, it should be recalled that during spermatogenesis DNA microfibrils unite into dense bundles containing virtually no intrastructural space (see electron-dense nucleic material of sperm cell in Fig. 2a). Sperm heads of fish and molluscs give X-ray diffraction patterns corresponding to those of micro-crystalline aggregates. In fact, the nucleoproteins of some spermatozoa exhibit such a high degree of organization or anisotropy, a property of liquid crystals, that they resemble the nucleoprotein crystals of plant viruses (Ginzburg 1972).

\section{Ingestion and digestion process}

TEM micrographs (Fig. 2) confirmed epifluorescence microscopy observations of intensive ingestion and digestion of Crassostrea virginica spermatozoa by microprotozoans. It is of particular interest in Fig. $2 \mathrm{~b}$ that intimate contact developed between the acrosomal membrane of the sperm cell and the cytoplasmic membrane of the protozoan. This invagination process was reminiscent of some peculiar form of fertilization. It was further noticed that, although cultures contained healthy populations of marsh bacteria $\left(10^{6}\right.$ to $10^{7}$ cells $\left.\mathrm{ml}^{-1}\right)$, ultrathin sections showed only a few protozoa $(<5 \%)$ with food vacuoles containing bacteria. This suggested some form of prey selectivity for gametes by 
salt-marsh microprotozoa. It was also noted that cells in the process of gamete digestion possessed enlarged mitochondria (Figs. 2C, d), an indication of enhanced metabolism (Fenchel 1982).

\section{Significance to the marine environment}

Organisms capable of gametogenesis and free release of gametes are ubiquitous in the marine environment, from coastal/benthic to pelagic areas, and even in deep sea benthos (Gooday 1988). External fertilization is widely distributed throughout the marine biota: in most invertebrate groups (e.g. molluscs, annelids, echinoderms, poriferans, coelenterates) and the majority of fish species, as well as in algae and protozoa (e.g. foraminiferans). Considering the amount of biomass expended in the reproductive phase, substantial amounts of organic material hithertho unaccounted for could be channelled into the marine food web via the 'reversed' link described here.

For example, one male specimen of Crassostrea virginica was calculated to produce $95 \mathrm{mg} \mathrm{C}, 35 \mathrm{mg} \mathrm{N}$ and $7 \mathrm{mg} \mathrm{P}$ or $220 \mathrm{mg}$ total dry weight in gametes per spawning. This compares well with other pelecypod molluscs, which shed ca $600 \mathrm{mg}$ dry weight in gametes per $40 \mathrm{~g}$ wet body weight annually (Katharina tunicata, a chiton; Giese \& Pearse 1979). Assuming a bivalve density of 25 ind. $\mathrm{m}^{-2}$ and a single annual spawning per species, $5500 \mathrm{~kg}$ of male gonadal material containing $2375 \mathrm{~kg} \mathrm{C}, 875 \mathrm{~kg} \mathrm{~N}$ and $164 \mathrm{~kg} \mathrm{P}$ would be released annually by the bivalve population in the saltmarsh studied. Thus, the potential bivalve sperm production $\left(55 \mathrm{t} \mathrm{km}^{-2}\right)$ in a salt-marsh is at least equal to the male gonad material released by Arcto-Norwegian codfish stocks (55 $\mathrm{t} \mathrm{km}^{-2}$ ) estimated by Dundas (1985).

Furthermore, invertebrates spawn several times a year, with different species spawning at different times, so the spawning season extends for 9 mo of the year in temperate salt-marshes. Abortive release of gametes during cold months for over-wintering could also supply pulses of a rich food source for microprotozoa late in the year, when bacteria and phytoplankton production are at a minimum. In conclusion, this alternative food web pathway needs to be fully documented and quantified, in order to be able to assess its importance to the energy budget in areas where gametogenesis occurs.

\section{Gametes as 'naturally produced microspheres'}

Fish and mollusc sperm retain good cellular integrity (DNA viability and locomotion) after prolonged storage, when frozen rapidly with glycerin and stored at $-79^{\circ} \mathrm{C}$ (Ginzburg 1972). Bivalves release about 1 to
$2 \times 10^{10}$ male gametes per spawning (calculated for Crassostrea virginica) in a few $\mathrm{cm}^{3}$ of ejaculate, which constitutes enough sperm stock to inoculate a large volume of experimental culture $\left(10^{4}\right.$ to $10^{5}$ fold dilution). Thus, ingestion of flagellated gametes could be used to yield relatively easy estimates of microprotozoa/protist grazing. Advantages in using these 'naturally produced microspheres' (Børsheim 1984, Cynar \& Sieburth 1986) as prey include: (1) live food (locomotion and cell surface properties important for prey recognition), (2) constant biovolume, (3) constant cellular contents (C:N:P ratios), (4) non-dividing, (5) longer digestion time than for bacteria, and (6) rich food source to estimate maximum growth rates of protists.

Acknowledgements. We thank Dan Hepworth for supplying bivalve gamete stocks, Patrice Mason for preparing samples for electron microscopy and F. Azam, K. Lochte, H.-G. Hoppe and $G$. Rheinheimer for helpful comments in the course of writing the manuscript. We are also grateful to F. Zuzarte for supplying information and literature on fish reproduction.

\section{LITERATURE CITED}

Azam, F., Fenchel, T., Field, J. G., Gray, J. S., Meyer-Reil L.-A., Thingstad, T. F. (1983). The ecological role of watercolumn microbes in the sea. Mar. Ecol. Prog. Ser 10: $257-263$

Børsheim, K. Y (1984). Clearance rates of bacteria-sized particles by freshwater ciliates, measured with monodisperse fluorescent latex beads. Oecologia (Berl.) 64: 286-288

Campbell, L., Carpenter, E. J. (1986). Estimating the grazing pressure of heterotrophic nanoplancton on Synechococcus sp. using the sea water dilution and selective inhibitor techniques. Mar Ecol. Prog. Ser. 33: 121-129

Cynar, F. J., Sieburth, J. McN. (1986). Unambiguous detection and improved quantification of phagotrophy in apochlorotic nanoflagellates using fluorescent microspheres and concomitant phase contrast and epifluorescence microscopy. Mar. Ecol. Prog. Ser. 32: 61-70

Dundas, I. E. D. (1985). Fate and possible effects of excessive sperm released during spawning. Mar. Ecol. Prog. Ser. 30: $28 \vec{t}-290$

Estep, K. W., Caron, D. A., Johnson, P. W., Sieburth, J. McN (1986). How important are oceanic algal nanoflagellates in bacterivory? Limnol. Oceanogr. 31: 646-650

Fenchel, T. (1982). Ecology of heterotrophic microflagellates. III. Adaptations to heterogeneous environments. Mar. Ecol. Prog. Ser. 9: 25-33

Giese, A. C., Pearse, J. S. (1979). Reproduction of marine invertebrates, Vol. V. Academic Press, London

Ginzburg, A. S. (1972). Fertilization in fishes and the problem of polyspermy. U.S. Department of Commerce, National Technical Information Service, Springfield, Virginia

Gooday, A. J. (1988). A response of benthic Foraminifera to the deposition of phytodetritus in the deep sea. Nature Lond. 332: 70-73

Haas, L. W (1982). Improved epifluorescence microscopy for observing planktonic micro-organisms. Ann. Inst. Oceanogr. 58 (Suppl.): 261-266

Lee, S., Fuhrman, J. A. (1987). Relationships between bio- 
volume and biomass of naturally derived marine bacterioplankton. Appl. environ. Microbiol. 53: 1298-1303

Pomeroy, L. R. (1974). The ocean's food web, a changing paradigm. Bioscience 24: 499-504

Rhodes, M. W., Anderson, I. C., Kator, H. I. (1983). In situ development of sublethal stress in Escherichia coli: effects on enumeration. Appl. environ. Microbiol. 45: 1870-1876 Suttle, C. A., Chan, A. M., Taylor, W D., Harrison, P. J. (1986). Grazing of planktonic diatoms by microflagellates. J. Plankton Res. 8: 393-398

This article was presented by Professor G. Rheinheimer; it was accepted for printing on November 14, 1988 